\title{
Pengaruh Penerapan Sistem Administrasi Perpajakan Modern, Kualitas Pelayanan dan Kesadaran Wajib Pajak Pada Kepatuhan WPOP
}

\author{
Ni Luh Putu Yunika Antari ${ }^{1}$ \\ Ni Luh Supadmi \\ ${ }^{1,2}$ Fakultas Ekonomi dan Bisnis Universitas Udayana (Unud), Bali, Indonesia \\ e-mail :yunikaantari28@gmail.com
}

\begin{abstract}
ABSTRAK
Tujuan penelitian ini adalah untuk mengetahui pengaruh penerapansistem administrasi perpajakan modern, kualitas pelayanan, dan kesadaran wajib pajak pada kepatuhan Wajib Pajak Orang Pribadi (WPOP). Penelitian ini dilakukan di KPP Pratama Denpasar Timur. Jumlah sampel yang diambil sebanyak 100 WPOP, dengan metode nonprobabilitysampling dengan teknik purposive sampling. Pengumpulan data dilakukan melalui wawancara, observasi non partisipan dan kuesioner. Teknik analisis data yang digunakan adalah regresi linier berganda. Berdasarkan hasil analisis diperoleh sistem administrasi perpajakan modern, kualitas pelayanan, dan kesadaran wajib pajak berpengaruh positif dan signifikan pada kepatuhan WPOP. Hal ini menunjukkan apabila sistem administrasi perpajakan yang diterapkan baik, maka akan cendrung meningkatkan kepatuhan pelaporan WPOP. Kualitas pelayanan juga berpengaruh positif pada kepatuhan WPOP, hal ini membuktikan bahwa semakin baik kualitas pelayanan yang diberikan akan membuat wajib pajak tersebut semakin patuh dalam memenuhi kewajibannya.
\end{abstract}

Kata Kunci: sistem administrasi perpajakan modern, kualitas pelayanan, dan kesadaran wajib pajak

\begin{abstract}
The purpose of this study was to determine the effect of the application of a modern tax administration system, service quality, and taxpayer awareness on individual taxpayer compliance (WPOP). This research was conducted at KPP Pratama Denpasar Timur. The data analysis technique used is multiple linear regression. Based on the results of the analysis obtained a modern tax administration system, service quality, and awareness of taxpayers have a positive and significant effect on WPOP compliance. This shows that if the tax administration system is implemented well, it will tend to increase compliance with WPOP reporting. Service quality also has a positive effect on WPOP compliance, this proves that the better the quality of services provided will make the taxpayer more compliant in fulfilling his obligations.
\end{abstract}

Keywords: modern tax administration system, service quality, and taxpayer awareness

\section{PENDAHULUAN}

Pajak merupakan sumber pendanaan dalam melaksanakan tanggung jawab negara untuk mengatasi masalah sosial, meningkatkan kesejahteraan dan kemakmuran serta menjadi kontrak sosial antara warga negara dengan pemerintah (Rusyadi, 2009). Pajak menurut Undang-Undang No. 28 tahun 2007 tentang Ketentuan Umum dan Tata Cara Perpajakan merupakan kontribusi wajib kepada negara yang 
terutang oleh pribadi maupun badan yang bersifat memaksa berdasarkan undangundang, dan tidak mendapatkan imbalan secara langsung serta digunakan sebesarbesarnya kemakmuran rakyat. Doran (2009) menyatakan kepatuhan Wajib Pajak untuk memenuhi kewajiban perpajakannya perlu ditingkatkan demi tercapainya target pajak yang diinginkan. Faktor yang memengaruhi penerimaan pajak suatu negara diantaranya adalah tingkat kepatuhan Wajib Pajak di negara tersebut (Chau, 2009).

Berdasarkan data Badan Pusat Statistik tahun 2017, jumlah pendapatan negara terbesar berasal dari sektor pajak. Realisasi penerimaan negara yang berasal dari pajak dan bukan pajak disajikan pada Tabel 1 berikut.

Tabel 1.

Realisasi Penerimaan Negara Tahun 2013 - 2017 (Dalam Milyar Rupiah)

\begin{tabular}{ccccc}
\hline Tahun & Penerimaan Pajak & $\begin{array}{c}\text { Persentase } \\
\text { Penerimaan } \\
\text { Pajak } \\
\text { (persen) }\end{array}$ & Penerimaan Bukan Pajak & $\begin{array}{c}\text { Persentase } \\
\text { Penerimaan } \\
\text { Bukan Pajak } \\
\text { (persen) }\end{array}$ \\
\hline 2013 & $1.077 .306,70$ & 17 & $354.751,90$ & 24 \\
2014 & $1.146 .865,80$ & 18 & $398.590,50$ & 27 \\
2015 & $1.240 .418,86$ & 19 & $255.628,48$ & 17 \\
2016 & $1.539 .166,20$ & 24 & $245.083,60$ & 16 \\
2017 & $1.495 .893,80$ & 23 & $240.362,90$ & 16 \\
\hline
\end{tabular}

Sumber: www.bps.go.id, 2017

Berdasarkan Tabel 1 menunjukkan bahwa penerimaan negara terbesar berasal dari sektor pajak dan mengalami peningkatan dari tahun 2013-2017, sedangkan penerimaan dari sektor bukan pajak mengalami penurunan. Hal tersebut membuktikan bahwa kontribusi pajak sangat signifikan dan terus meningkat dari tahun ke tahun sebagai sumber penerimaan negara. 
Salah satu masalah yang paling serius bagi para pembuat kebijakan ekonomi adalah mendorong tingkat kepatuhan wajib pajak (Togler, 2005). Kepatuhan pajak yang tidak meningkat akan mengancam upaya pemerintah untuk meningkatkan kesejahteraan masyarakat (Chau dan Leung, 2009). Kepatuhan wajib pajak adalah upaya wajib pajak sebagai warga negara dalam memenuhi kewajiban perpajakannya secara sukarela sehingga dapat meningkatkan penerimaan pajak dan memberikan kontribusi bagi pembangunan negara (Megawangi dan Setiawan, 2016). Kepatuhan perpajakan merupakan suatu kedisiplinan yang dimiliki oleh wajib pajak untuk melaksanakan kewajibannya dibidang perpajakan sesuai dengan undang-undang yang berlaku (Yasa dan Jati, 2017). Wajib pajak patuh akan kewajibannya karena menganggap kepatuhan terhadap pajak adalah suatu norma (Lederman, 2003).

Terdapat beberapa faktor yang memengaruhi kepatuhan wajib pajak dalam membayar kewajiban perpajakannya. Studi kepatuhan pajak menunjukkan bahwa banyak faktor dampak ekonomi, sosial, psikologis dan demografis terhadap perilaku kepatuhan pembayar pajak (Redae dan Sekhon, 2017). Rustiyaningsih (2011) menyimpulkan bahwa pemahaman terhadap self assessment system, kualitas pelayanan, tingkat pendidikan, tingkat penghasilan, persepsi wajib pajak terhadap sanksi perpajakan memengaruhi kepatuhan wajib pajak dalam melaksanakan kewajiban perpajakan. Putri dan Jati (2013) menyatakan bahwa faktor-faktor kesadaran wajib pajak, kewajiban moral, kualitas pelayanan dan sanksi perpajakan berpengaruh pada kepatuhan wajib pajak. Penelitian Siat dan Toly (2013) membuktikan bahwa faktor kesadaran perpajakan, sikap fiskus, 
hukum pajak, dan sikap rasional secara simultan dan secara parsial berpengaruh signifikan terhadap kepatuhan wajib pajak di Surabaya. Faktor-faktor yang memengaruhi kepatuhan wajib pajak berdasarkan penelitian Nalendro dan Isgiyarta (2014) adalah kesadaran membayar pajak, pengetahuan dan pemahaman peraturan perpajakan, persepsi kondisi keuangan. Pamuji dkk. (2014) menyatakan bahwa kepatuhan wajib pajak dipengaruhi secara signifikan oleh pemahaman perpajakan, pengawasan dan sosialisasi. Penelitian yang dilakukan oleh Putra dan Jati (2017) menyatakan bahwa kesadaran wajib pajak, kewajiban moral, pengetahuan pajak dan persepsi tentang sanksi perpajakan berpengaruh pada kepatuhan wajib pajak.

Pemerintah melalui Direktorat Jenderal Pajak (DJP) terus melaksanakan terobosan untuk mengoptimalkan penerimaan pajak melalui kebijakan-kebijakan yang dikeluarkan.Salah satu langkah yang diambil oleh Direktorat Jendral Pajak adalah melakukan reformasi di bidang perpajakan (tax reform). Reformasi perpajakan yang dilakukan melalui program modernisasi administrasi perpajakan. Reformasi di bidang perpajakan dilaksanakan melalui program modernisasi administrasi perpajakan. Konsep program ini adalah perubahan pola pikir dan perilaku aparat serta tata nilai organisasi, sehingga dapat menjadikan Direktorat Jendral Pajak sebagai institusi yang profesional dengan citra yang baik dimata masyarakat. Pelaksanaan modernisasi administrasi perpajakan mencakup 4 hal utama, yaitu (1) restrukturisasi organisasi berdasarkan fungsi; (2) penyempurnaan proses bisnis melalui optimalisasi penggunaan teknologi komunikasi dan informasi yang mengarah kepada full automation (automasi lengkap); (3) 
penyempurnaan sistem manajemen sumber daya manusia melalui pengembangan manajemen sumber daya manusia berbasis kompetensi yang berlandaskan prinsip "transparency, fairness, dan performance based"; dan (4) penerapan Kode Etik Pegawai secara tegas pada semua lini organisasi untuk menjamin terwujudnya pelaksanaan "good governance". Reformasi administrasi ini mempunyai tiga tujuan utama, yakni meningkatkan kepatuhan sukarela Wajib Pajak, meningkatkan kepercayaan masyarakat, dan meningkatkan produktivitas dan integritas aparat pajak (DJP, 2007).

Adanya bukti empiris keterkaitan antara modernisasi sistem administrasi perpajakan dengan tingkat kepatuhan Wajib Pajak dinyatakan oleh Slemrod dan Kopczuk (2002) dengan argumen bahwa modernisasi administrasi perpajakan ini akan efektif dalam peningkatan kepatuhan jika diikuti dengan perancangan dan pelaksanaan hukum pajak secara konsisten. Menurut Petrus Lumbantoruan (2014) semakin ditingkatkannya penerapan sistem administrasi perpajakan modern, maka kepatuhan Wajib Pajak akan semakin meningkat. Pentingnya peran modernisasi administrasi pajak dalam meningkatkan kepatuhan Wajib Pajak seperti dinyatakan oleh Ghimire (2006) bahwa prosedur pajak perlu dibuat lebih sederhana dan mudah dalam upaya meningkatkan kepatuhan.Modernisasi perpajakan yaitu penerapan sistem administrasi perpajakan yang transparan dan akuntabel, dengan memanfaatkan teknologi informasi yang handal dan terkini dapat meningkatkan kepatuhan Wajib Pajak (Kennedy, 2007). Niemirowski et al. (2003) menyatakan bahwa opini pribadi berdasarkan penilaian, seperti sistem administrasi perpajakan 
yang adil dan profesional memengaruhi kepatuhan dan ketidakpatuhan terhadap pajak.

Palupi (2010) dalam penelitiannya membuktikan bahwa modernisasi sistem administrasi perpajakan yang berdimensi restrukturisasi organisasi, proses bisnis dan teknologi informasi, dan penyempurnaan Sumber Daya Manusia (SDM) berpengaruh signifikan pada kepatuhan Wajib Pajak di KPP Pratama Jakarta Gambir Empat. Hal ini didukung oleh penelitian yang dilakukan oleh Aprilia (2013), Wiranatha dan Rasmini (2017), Dewi dan Ery (2017) yang membuktikan bahwa sistem administrasi perpajakan modern berpengaruh positif terhadap kepatuhan Wajib Pajak. Hasil tersebut berbeda dengan penelitian yang diperoleh oleh Irawan (2013), yang memeroleh hasil bahwa tidak ada pengaruh sistem administrasi perpajakan modern pada kepatuhan Wajib Pajak di KPP Madya Palembang. Hasil tersebut juga diperoleh dari penelitian yang dilakukan oleh Candra, dkk (2013) serta Darmayasa (2016), yang membuktikan bahwa proses bisnis dan teknologi informasi serta komunikasi dalam modernisasi sistem administrasi perpajakan tidak berpengaruh pada kepatuhan Wajib Pajak di KPP Badung Utara. Selain melakukan modernisasi administrasi perpajakan, kualitas pelayanan salah satu hal yang penting yang diperhatikan dengan maksud agar masyarakat memiliki kemauan untuk melunasi kewajiban pajaknya.

Parasuraman, et al. (1985) mendefinisikan kualitas pelayanan sebagai kemampuan organisasi untuk memenuhi atau melebihi harapan pelanggan. Pelayanan yang berkualitas adalah pelayanan yang dapat memberikan kepuasan kepada pelanggan dan tetap dalam batas memenuhi standar pelayanan yang dapat 
dipertangungjawabkan serta harus dilakukan secara terus-menerus (Supadmi, 2009). Kualitas pelayanan berperan besar terhadap peningkatan kepatuhan wajib pajak dalam hal penerimaan pajak. Petugas pajak harus memberikan pelayanan dan kinerja yang baik kepada wajib pajak sehingga dapat meningkatkan kepatuhan wajib pajak untuk memenuhi kewajiban pajaknya. Kualitas pelayanan inilah yang harus selalu dibenahi dan ditingkatkan oleh pemerintah. Adanya rasa puas atas pelayanan yang diberikan oleh pemerintah diharapkan akan memberi motivasi dan kesadaran dari wajib pajak untuk melaksanakan kewajiban perpajakannya (Sentanu dan Setiawan, 2016). Supadmi (2009) mengatakan bahwa untuk meningkatkan kepatuhan wajib pajak dapat dilakukan melalui kualitas pelayanan. Kualitas pelayanan juga dinilai sebagai perbandingan antara harapan yang diinginkan oleh pelanggan dengan penilaian mereka terhadap kinerja aktual dari suatu penyediaan layanan (Cronin, 1992).

Penelitian Dharma dan Suardana (2014), Prabawa dan Noviari (2012) menunjukkan bahwa kualitas pelayanan berpengaruh signifikan terhadap kepatuhan wajib pajak. Hal tersebut didukung oleh penelitian yang dilakukan oleh Utama (2013), Widiastuti dan Laksito (2014), Dewi dan Supadmi (2014), Sukarma dan Wirama (2016), Megawangi dan Setiawan (2016), dan Rusmayani dan Supadmi (2017) membuktikan bahwa kualitas pelayanan berpengaruh signifikan dan positif terhadap kepatuhan wajib pajak. Hal tersebut tidak didukung oleh penelitian Rukmana (2013), Munawaroh, dkk. (2014) dan Novitasari (2015) menunjukkan bahwa kualitas pelayanan tidak berpengaruh terhadap kepatuhan wajib pajak. Patmasari, dkk. (2016) juga menyatakan bahwa 
Ni Luh Putu Yunika Antari dan Ni Luh Supadmi. Pengaruh...

variabel pelayanan pajak tidak berpengaruh signifikan dan negatif terhadap kepatuhan wajib pajak.Tinggi rendahnya Kepatuhan Wajib Pajak juga dipengaruhi oleh kesadaran Wajib Pajak.

Kesadaran Wajib Pajak merupakan hal yang penting dalam perpajakan untuk meningkatkan kepatuhan Wajib Pajak. Ritongga (2011) menyatakan bahwa kesadaran Wajib Pajak dalam membayar pajak merupakan perilaku Wajib Pajak yang berupa pandangan atau perasaan yang melibatkan pengetahuan, keyakinan, dan penalaran disertai kecendrungan untuk bertindak sesuai peraturan yang diberikan oleh sistem dan ketentuan pajak tersebut. Kesadaran Wajib Pajak dapat dilihat dari kesungguhan dan keinginan Wajib Pajak untuk memenuhi kewajiban pajaknya yang ditunjukkan dalam pemahaman Wajib Pajak dalam membayar dan melaporkan pajak (Putri dan Jati, 2004). James \& Nobes (1997) menyatakan kesadaran masyarakat yang tinggi akan mendorong semakin banyak masyarakat memenuhi kewajibannya untuk mendaftarkan diri sebagai Wajib Pajak, melaporkan dan membayar pajaknya dengan benar sebagai wujud tanggung jawab berbangsa dan bernegara. Penelitian yang dilakukan Megawangi (2016), Santi dan Lely (2017), Pratiwi dan Ery (2014) membuktikan bahwa kesadaran Wajib Pajak berpengaruh positif pada kepatuhan Wajib Pajak. Hal tersebut juga didukung oleh penelitian-penelitian yang dilakukan oleh Rohmawati dan Rasmini (2012) serta Dewi dan Lely (2017). Putra dan Lely (2018) yang membuktikan bahwa kesadaran wajib pajak berpengaruh negatif pada kepatuhan wajib pajak kendaraan bermotor di Kabupaten Gianyar Berdeda dengan hasil penelitian yang dilakukan oleh Dewi dan Lely (2018) yang membuktikan bahwa kesadaran wajib pajak 
berpengaruh negatif pada kepatuhan Wajib Pajak Orang Pribadi di Kantor Pelayanan Pajak Pratama Badung Utara.

KPP Pratama Denpasar Timur dipilih sebagai lokasi penelitian karena tidak memenuhi target kepatuhan Wajib Pajak yang telah ditetapkan oleh Direktorat Jenderal Pajak yaitu sebesar $72.50 \%$. Tingkat kepatuhan WPOP pada KPP Pratama Denpasar Timur mengalami fluktuasi pada periode 2013-2017. Ketidakstabilan yang terjadi pada tingkat kepatuhan WPOP menjadi alasan peneliti untuk melakukan penelitian kembali mengenai faktor apa saja yang yang memengaruhi kepatuhan WPOP pada KPP Pratama Denpasar Timur. Berikut ini tingkat kepatuhan pelaporan SPT Tahunan WPOP di KPP Pratama Denpasar Timur tahun 2013-2017 dapat dilihat pada Tabel 2 berikut.

Tabel 2.

Tingkat Kepatuhan WPOP di Kantor Pelayanan Pajak Pratama Denpasar Timur 2013-2017

\begin{tabular}{cccccc}
\hline $\begin{array}{c}\text { Tahu } \\
\mathbf{n}\end{array}$ & $\begin{array}{c}\text { WPOP } \\
\text { Terdaftar } \\
\text { (orang) }\end{array}$ & $\begin{array}{c}\text { WPOP } \\
\text { Efektif } \\
\text { (orang) }\end{array}$ & $\begin{array}{c}\text { WPOP Terdaftar Wajib } \\
\text { SPT } \\
\text { (orang) }\end{array}$ & $\begin{array}{c}\text { Realisa } \\
\text { si SPT } \\
\text { (orang) }\end{array}$ & $\begin{array}{c}\text { Persentas } \\
\mathbf{e} \\
\text { Kepatuha } \\
\mathbf{n}(\boldsymbol{\%})\end{array}$ \\
\hline 2013 & 91.440 & 59.108 & 59.030 & 36.368 & 61.53 \\
2014 & 83.926 & 63.477 & 53.710 & 35.820 & 58.43 \\
2015 & 87.652 & 58.148 & 51.078 & 36.928 & 54.19 \\
2016 & 91.084 & 72.774 & 51.662 & 41.175 & 56.54 \\
2017 & 96.053 & 52.417 & 52.417 & 39.769 & 54.57 \\
\hline
\end{tabular}

Sumber: Data diolah, 2017

Tabel 2 menunjukkan persentase kepatuhan WPOP yang berada di lingkungan KPP Pratama Denpasar Timur mengalami penurunan dari tahun 20132017 meskipun terdapat peningkatan jumlah WPOP yang terdaftar. Persentase kepatuhan WPOP pada tahun 2013 sebesar 61,53 persen mengalami penurunan menjadi 58,43 persen di tahun 2014 dan 54,19 persen pada tahun 2015. Pada 
tahun 2016 tingkat kepatuhan WPOP mengalami peningkatan menjadi 56,54 persen dan kembali mengalami penurunan pada tahun 2017 menjadi 54,57 persen. Tingkat kepatuhan WPOP di KPP Pratama Denpasar Timur ini menunjukkan persentase tingkat kepatuhan yang masih rendah. Hal tersebut memotivasi peneliti untuk meneliti kepatuhan wajib pajak di KPP Pratama Denpasar Timur.

Administrasi perpajakan berperan penting dalam sistem perpajakan di suatu Negara. Suatu Negara dapat dengan sukses mencapai sasaran yang diharapkan dalam menghasilkan penerimaan pajak yang optimal karena administrasi perpajakannya mampu dengan efektif melaksanakan sistem perpajakan di suatu Negara yang dipilih. Semakin baik modernisasi sistem administrasi perpajakan yang diterapkan untuk memermudah Wajib Pajak dalam melaporkan, menghitung dan membayar kewajiban pajaknya maka kepatuhan Wajib Pajak akan meningkat. Fahmi (2014) meneliti tentang modernisasi sistem administrasi perpajakan terhadap tingkat kepatuhan pengusaha kena pajak di KPP Pratama Padang. Hasil penelitian menunjukkan bahwa ada pengaruh positif antara modernisasi sistem perpajakan dengan tingkat kepatuhan Wajib Pajak.

Hasil tersebut sejalan dengan penelitian yang dilakukan oleh Madewing (2013) yang meneliti tentang Pengaruh Modernisasi Sistem Administrasi Perpajakan terhadap kepatuhan Wajib Pajak pada KPP Pratama Makasar Utara. Hasil penelitian tersebut menunjukkan bahwa modernisasi sistem administrasi perpajakan berpengaruh positif terhadap kepatuhan Wajib Pajak di KPP Pratama Makasar. Hal tersebut didukung oleh penelitian-penelitian yang dilakukan oleh Wiranatha dan Rasmini (2017), Dewi dan Ery (2017). 
Berdasarkan uraian tersebut, hipotesis yang dapat dikembangkan adalah sebagai berikut.

$\mathrm{H}_{1}$ : $\quad$ Sistem administrasi perpajakan modern berpengaruh positif pada kepatuhan Wajib Pajak Orang Pribadi di KPP Pratama Denpasar Timur.

Kualitas pelayanan dapat diukur dengan kemampuan memberikan pelayanan yang memuaskan, dapat memberikan pelayanan dengan tanggapan, kemampuan, kesopanan, dan sikap dapat dipercaya yang dimiliki oleh aparat pajak. Kepatuhan Wajib Pajak dapat diukur dari pemahaman terhadap semua ketentuan peraturan perundang-undangan perpajakan, mengisi formulir dengan lengkap dan jelas, menghitung jumlah pajak yang terutang dengan benar, membayar dan melaporkan pajak yang terutang tepat pada waktunya (Supadmi, 2009).

Penelitian yang dilakukan oleh Diatnyani (2010) dan Arista S. (2011) menemukan bahwa kualitas pelayanan berpengaruh positif pada kepatuhan Wajib Pajak. Hal tersebut didukung oleh penelitian-penelitian yang dilakukan oleh Utama (2013), Widiastuti dan Laksito (2014), Dewi dan Supadmi (2014), Sukarma dan Wirama (2016), Megawangi dan Setiawan (2016), dan Rusmayani dan Supadmi (2017) yang membuktikan bahwa kualitas pelayanan berpengaruh positif dan signifikan terhadap kepatuhan wajib pajak.

$\mathrm{H}_{2}$ : Kualitas pelayanan berpengaruh positif pada kepatuhan Wajib Pajak Orang Pribadi di KPP Pratama Denpasar Timur

Kesadaran Wajib Pajak dalam teori konsensus merupakan salah satu faktor yang dapat memengaruhi prilaku kepatuhan Wajib Pajak dalam membayar pajak. Kesadaran Wajib Pajak merupakan kondisi dimana Wajib Pajak mengetahui, 
mematuhi, dan melaksanakan kewajiban perpajakan dengan benar dan sukarela. Apabila pemahaman dan pelaksanaan kewajiban perpajakan semakin baik, maka tingkat kesadaran Wajib Pajak semakin tinggi sehingga diharapkan dapat meningkatkan kepatuhan perpajaknnya (Muliari dan Ery, 2011). Pernyataan ini didukung oleh teori kepatuhan yang dikemukakan oleh Green (1991), bahwa kepatuhan dianggap sebagai perubahan prilaku dari prilaku mereka yang tidak menaati peraturan menjadi menaati peraturan.

Penelitian yang dilakukan Megawangi (2016) dan Pratiwi dan Ery (2014) membuktikan bahwa kesadaran Wajib Pajak berpengaruh positif pada kepatuhan Wajib Pajak. Hal tersebut juga didukung oleh penelitian-penelitian yang dilakukan oleh Rohmawati dan Rasmini (2012) serta Dewi dan Lely (2017) yang membuktikan bahwa kesadaran Wajib Pajak, penyuluhan, pelayanan, dan sanksi perpajakan berpengaruh positif pada kepatuhan Wajib Pajak Orang Pribadi.

$\mathrm{H}_{3}$ : $\quad$ Kesadaran Wajib Pajak berpengaruh positif pada kepatuhan Wajib Pajak Orang Pribadi di KPP Pratama Denpasar Timur.

\section{METODE PENELITIAN}

Berdasarkan hipotesis variabel-variabel penelitian tersebut, maka desain penelitian disajikan pada Gambar 1 berikut ini.

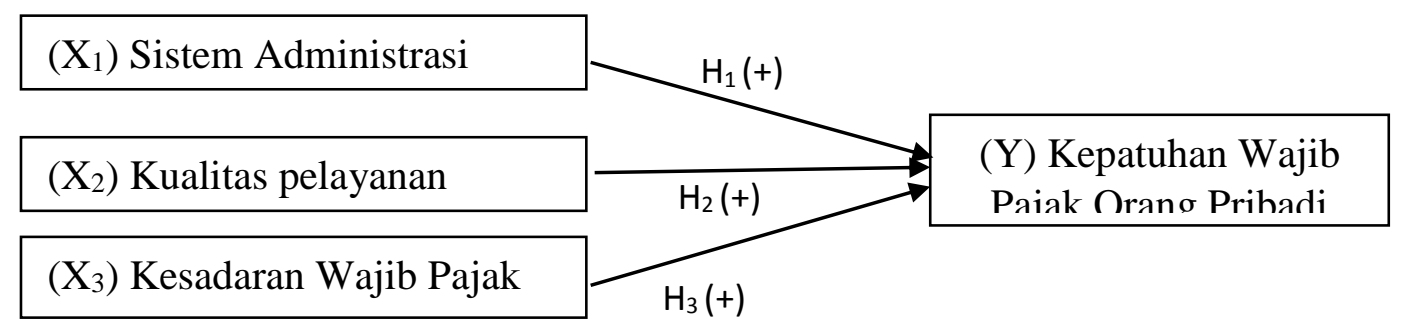

Gambar 1. Desain Penelitian

Sumber: Data diolah, 2018 
Penelitian ini dilakukan di Kantor Pelayanan Pajak Pratama Denpasar Timur beralamat di Jalan Kapten Tantular No. 4 GKN II, Denpasar. KPP Pratama Denpasar Timur dipilih sebagai lokasi penelitian ialah dikarenakan tidak memenuhi target kepatuhan Wajib Pajak yang telah ditetapkan oleh Direktorat Jenderal Pajak yaitu sebesar 72,50 persen. Tingkat kepatuhan WPOP pada lokasi penelitian mengalami fluktuasi pada periode 2013-2017. Ketidakstabilan yang terjadi pada tingkat kepatuhan WPOP menjadi alasan peneliti untuk melakukan penelitian kembali mengenai faktor yang memengaruhi kepatuhan WPOP pada KPP Pratama Denpasar Timur.

Populasi dalam penelitian ini adalah seluruh Wajib Pajak Orang Pribadi yang terdaftar di KPP Pratama Denpasar Timur per 31 Desember 2017 yaitu sejumlah 96.053 Wajib Pajak. Metode penentuan sampel yang digunakan dalam penelitian ini adalah metode nonprobability sampling dengan teknik purposive sampling.

Wajib Pajak Orang Pribadi efektif yang terdaftar di Kantor Pelayanan Pajak Pratama Denpasar Timur digunakan rumus slovin, sebagai berikut.

$$
\mathrm{n}=\frac{\mathrm{N}}{\left(1+\mathrm{Ne}^{2}\right)}
$$

Keterangan :

$$
\begin{aligned}
& \mathrm{n}=\text { jumlah anggota sampel } \\
& \mathrm{N}=\text { jumlah anggota populasi } \\
& \mathrm{e}=\text { batas kesalahan } 10 \%(0,1)
\end{aligned}
$$

Perhitungan sampel :

$$
\mathrm{n}=\frac{52.417}{\left(1+52.417(0,1)^{2}\right.}
$$




$$
\begin{aligned}
& =\frac{52.417}{525,17} \\
& =99,80
\end{aligned}
$$

Dibulatkan menjadi 100. Maka jumlah responden dalam penelitian ini berjumlah 100 orang.

Analisis regresi linier berganda adalah hubungan secara linier antara dua atau lebih variabel independen $\left(\mathrm{X}_{1}, \mathrm{X}_{2}, \ldots \mathrm{X}_{\mathrm{n}}\right)$ dengan variabel dependen (Y)(Sugiyono, 2017:277). Teknik analisis ini digunakan untuk mengetahui atau memperoleh gambaran mengenai pengaruh variabel bebas terhadap variabel terikat. Analisis regresi yang digunakan dalam penelitian ini adalah analisis regresi linear berganda yang diuji dengan tingkat signifikan 0,05.Model regresi linear berganda ini dirumuskan sebagai berikut.

$$
\mathrm{Y}=\alpha+\beta_{1} \mathrm{X}_{1}+\beta_{2} \mathrm{X}_{2}+\beta_{3} \mathrm{X}_{3}+\mathrm{e}
$$

\section{Keterangan:}

$\mathrm{Y}=$ Kepatuhan Wajib Pajak Orang Pribadi

$\alpha=$ Konstanta

$\beta=$ Koefisien Regresi

$\mathrm{X}_{1}=$ Sistem Administrasi Perpajakan Modern

$\mathrm{X}_{2}=$ Kualitas Pelayanan

$\mathrm{X}_{3}=$ Kesadaran Wajib Pajak

$\mathrm{e}=$ Standar error

\section{HASIL DAN PEMBAHASAN}

Analisis statistik deskriptif adalah pengujian statistik yang digunakan untuk menganalisis data dengan memberikan gambaran atau deskripsi terhadap suatu 
data mengenai nilai rata-rata (mean), standar deviasi, maksimum dan minimum. Hasil uji statistik deskriptif dapat dilihat pada Tabel 3.berikut:

Tabel 3.

Hasil Uji Analisis Statistik Deskriptif

\begin{tabular}{lrrrrr}
\hline & N & Minimum & Maximum & \multicolumn{1}{c}{ Mean } & Std. Deviation \\
\hline Sistem Administrasi & 100 & 13 & 40 & 28.54 & 5.126 \\
Perpajakan Modern & & & & & \\
Kualitas Pelayanan & 100 & 14 & 28 & 19.98 & 2.689 \\
Kesadaran Wajib Pajak & 100 & 3 & 12 & 9.12 & 1.914 \\
Kepatuhan WPOP & 100 & 11 & 20 & 16.39 & 2.224 \\
Valid N (listwise) & 100 & & & & \\
\hline
\end{tabular}

Sumber: Data diolah, 2018

Rata-rata (Mean) digunakan untuk mengukur nilai sentral dari suatu distribusi data dan standar deviasi digunakan untuk mengukur perbedaan nilai data yang diteliti dengan nilai rata-ratanya. Tabel 3. menunjukkan hasil statistik deskriptif yaitu variabel sistem administrasi perpajakan modern memiliki nilai minimum 13 dan nilai maksimum 40. Nilai rata-rata untuk variabel sistem administrasi sebesar 28,54 dengan penyimpangan sebesar 5,12. Hal ini berarti berdasarkan hasil statistik deskriptif, terjadi perbedaan nilai sistem administrasi yang diteliti terhadap nilai rata-ratanya sebesar 5,12.

Variabel kualitas pelayanan memiliki nilai minimum 14 dan nilai maksimum 28. Nilai rata-rata untuk variabel kualitas pelayanan sebesar 19,98 dengan penyimpangan sebesar 2,68.Hal ini berarti berdasarkan hasil statistik deskriptif, terjadi perbedaan nilai kualitas pelayanan yang diteliti terhadap nilai rata-ratanya sebesar 2,68.

Variabel kesadaran wajib pajak memiliki nilai minimum 3 dan nilai maksimum 12. Nilai rata-rata untuk variabel kesadaran wajib pajak sebesar 9,12 dengan penyimpangan sebesar 1,91.Hal ini berarti berdasarkan hasil statistik 
deskriptif, terjadi perbedaan nilai kesadaran wajib pajak yang diteliti terhadap nilai rata-ratanya sebesar 1,91 .

Variabel kepatuhan WPOP memiliki nilai minimum dan nilai maksimum 22,71. Nilai rata-rata untuk variabel kepatuhan WPOP sebesar 16,39 dengan penyimpangan sebesar 2,22. Hal ini berarti berdasarkan hasil statistik deskriptif, terjadi perbedaan nilai kepatuhan WPOP yang diteliti terhadap nilai rata-ratanya sebesar 2,22.

Analisis regresi linear berganda ini digunakan untuk menganalisis pengaruh Sistem administrasi perpajakan modern $\left(\mathrm{X}_{1}\right)$, Kualitas pelayanan $\left(\mathrm{X}_{2}\right)$, dan Kesadaran wajib pajak $\left(\mathrm{X}_{3}\right)$, pada Kepatuhan wajib pajak orang pribadi (Y). Analisis regresi linear berganda diolah dengan bantuan software SPSS 22 for Windows dengan hasil yang dapat dilihat pada Tabel 4. berikut.

Tabel 4.

Hasil Analisis Regresi Linear Berganda

\begin{tabular}{|c|c|c|c|c|c|c|}
\hline \multirow{2}{*}{\multicolumn{2}{|c|}{ Variabel }} & \multicolumn{2}{|c|}{$\begin{array}{l}\text { Unstandardized } \\
\text { Coefficients }\end{array}$} & \multirow{2}{*}{$\begin{array}{c}\text { Standardized } \\
\text { Coefficients } \\
\text { Beta }\end{array}$} & \multirow[t]{2}{*}{$\mathrm{T}$} & \multirow[t]{2}{*}{ Sig. } \\
\hline & & B & $\begin{array}{l}\text { Std. } \\
\text { Error }\end{array}$ & & & \\
\hline (constant) & & 6.249 & 1.462 & & 4.273 & .000 \\
\hline $\begin{array}{l}\text { Sistem administrasi } \\
\text { modern }\end{array}$ & perpajakan & .103 & .043 & .236 & 2.383 & .019 \\
\hline Kualitas pelayanan & & .225 & .079 & .272 & 2.857 & .005 \\
\hline Kesadaran wajib pajak & & .299 & .106 & .257 & 2.809 & .006 \\
\hline
\end{tabular}

Sumber:Data diolah, 2018

Dari hasil analisis regresi linear berganda pada Tabel 4. tersebut, maka dapat dibuat persamaan sebagai berikut.

$$
Y=6,249+0,103 X_{1}+0,225 X_{2}+0,299 X_{3}
$$

Nilai konstanta $(\beta)$ sebesar 6,249 memiliki arti bahwa variabel sistem administrasi perpajakan modern, kualitas pelayanan, dan kesadaran wajib pajak berpengaruh positif pada variabel kepatuhan Wajib Pajak Orang Pribadi. 
Nilai koefisien $\beta_{1}$ sebesar 0,103 . Nilai koefisien bernilai positif menunjukan bahwa apabila sistem administrasi perpajakan modern $\left(\mathrm{X}_{1}\right)$ meningkat, maka kepatuhan wajib pajak orang pribadi akan cendrung mengalami peningkatan dengan asumsi variabel bebas lainnya konstan.

Nilai koefisien $\beta_{2}$ sebesar 0,225 . Nilai koefisien bernialai positif menunjukan bahwa apabila nilai kualitas pelayanan $\left(\mathrm{X}_{2}\right)$ meningkat, maka kepatuhan wajib pajak orang pribadi akan cendrung mengalami peningkatan dengan asumsi variabel bebas lainnya konstan.

Nilai koefisien $\beta_{3}$ sebesar 0,299. Nilai koefisien bernilai positif menunjukan bahwa apabila kesadaran wajib pajak $\left(\mathrm{X}_{3}\right)$ meningkat, maka kepatuhan wajib pajak orang pribadi akan mengalami peningkatan sebesar 0,299 dengan asumsi variabel bebas lainnya konstan.

Nilai koefisien regresi masing-masing variabel bebas bernilai positif dengan nilai signifikansi uji t kurang dari 0,05 . Hal ini menunjukkan bahwa semua variabel bebas memiliki pengaruh positif yang signifikan terhadap variabel terikat.

Uji kelayakan model (uji F) dilakukan untuk mengetahui kelayakan model penelitian yang digunakan sebagai alat analisis untuk menguji pengaruh variabel independen terhadap variabel dependen. Hasil uji kelayakan model (uji F) dapat dilihat pada Tabel 5. berikut ini:

Tabel 5.

Hasil Uji Kelayakan Model (Uji F)

\begin{tabular}{llrrrrr}
\hline Model & & Sum of Squares & df & Mean Square & F & \multicolumn{1}{c}{ Sig. } \\
\hline 1 & Regression & 174.498 & 3 & 58.166 & 17.710 & $.000^{\text {a }}$ \\
& Residual & 315.292 & 96 & 3.284 & & \\
& Total & 489.790 & 99 & & & \\
\hline
\end{tabular}

Sumber: Data diolah, 2018 
Berdasarkan Tabel 5 hasil uji F menunjukkan nilai F hitung sebesar 17.710 dengan nilai $p$-value sebesar 0,000. Dapat disimpulkan seluruh variabel independen yaitu sistem administrasi perpajakan modern, kualitas pelayanan, dan kesadaran wajib pajak mampu memprediksi atau menjelaskan fenomena kepatuhan wajib pajak orang pribadi di Kantor Pelayanan Pajak Pratama Denpasar Timur. Hal ini berarti model dapat digunakan untuk analisa lebih lanjut atau dengan kata lain model dapat digunakan untuk memproyeksikan karena hasil goodness of fitnya baik dengan nilai signifikansi $\mathrm{P}$ value 0,000 .

Mengetahui dan mengukur kemampuan model dalam menerangkan variasi variabel independen digunakan koefisien determinasi $\left(R^{2}\right)$. Peneliti menggunakan nilai adjusted $R^{2}$ pada saat mengevaluasi yang mana model regresi terbaik, karena tidak seperti $R^{2}$, nilai adjusted $R^{2}$ dapat naik atau turun apabila satu variabel independen ditambahkan ke dalam model.

Tabel 6.

Hasil Uji Koefisien Determinasi

\begin{tabular}{|c|c|c|c|c|}
\hline Model & $\mathbf{R}$ & R Square & Adjusted R Square & $\begin{array}{l}\text { Std. Error of the } \\
\text { Estimate }\end{array}$ \\
\hline 1 & $.597^{\mathrm{a}}$ & .356 & .336 & 1.812 \\
\hline
\end{tabular}

Hasil uji koefisien determinasi dalam Tabel 6. menunjukkan besarnya nilai adjusted $R^{2}$ (koefisien determinasi yang telah disesuaikan) adalah 33,6. Ini berarti variasi Kepatuhan wajib pajak orang pribadi dapat dipengaruhi secara signifikan oleh variabel sistem administrasi perpajakan modern, kualitas pelayanan, dan kesadaran wajib pajak sebesar 33,6 persen sedangkan sisanya sebesar 66,4 persen dijelaskan oleh faktor lain. 
Berdasarkan Tabel 6. hasil uji $\mathrm{F}$ menunjukkan nilai $\mathrm{F}$ hitung sebesar 17.710 dengan nilai $p$-value sebesar 0,000. Dapat disimpulkan seluruh variabel independen yaitu sistem administrasi perpajakan modern, kualitas pelayanan, dan kesadaran wajib pajak mampu memprediksi atau menjelaskan fenomena kepatuhan wajib pajak orang pribadi di Kantor Pelayanan Pajak Pratama Denpasar Timur. Hal ini berarti model dapat digunakan untuk analisa lebih lanjut atau dengan kata lain model dapat digunakan untuk memproyeksikan karena hasil goodness of fitnya baik dengan nilai signifikansi $\mathrm{P}$ value 0,000 .

Mengetahui dan mengukur kemampuan model dalam menerangkan variasi variabel independen digunakan koefisien determinasi $\left(R^{2}\right)$. Peneliti menggunakan nilai adjusted $R^{2}$ pada saat mengevaluasi yang mana model regresi terbaik, karena tidak seperti $R^{2}$, nilai adjusted $R^{2}$ dapat naik atau turun apabila satu variabel independen ditambahkan ke dalam model.

Tabel 7.

Hasil Uji Koefisien Determinasi

\begin{tabular}{|c|c|c|c|c|}
\hline Model & $\mathbf{R}$ & R Square & Adjusted R Square & $\begin{array}{l}\text { Std. Error of the } \\
\text { Estimate }\end{array}$ \\
\hline$\overline{1}$ & $.597^{\mathrm{a}}$ & .356 & .336 & 1.812 \\
\hline
\end{tabular}

Hasil uji koefisien determinasi dalam Tabel 7. menunjukkan besarnya nilai adjusted $R^{2}$ (koefisien determinasi yang telah disesuaikan) adalah 33,6. Ini berarti variasi Kepatuhan wajib pajak orang pribadi dapat dipengaruhi secara signifikan oleh variabel sistem administrasi perpajakan modern, kualitas pelayanan, dan kesadaran wajib pajak sebesar 33,6 persen sedangkan sisanya sebesar 66,4 persen dijelaskan oleh faktor lain. 
Berdasarkan Tabel 4. diperoleh nilai t untuk variabel sistem administrasi sebesar 2,383 dan nilai signifikansi uji t sebesar 0,019 lebih kecil dari $\alpha=0,05$ dan nilai koefisien regresi sebesar 0,103 maka $\mathrm{H}_{1}$ diterima. Hasil pengujian menunjukkan bahwa sistem administrasi perpajakan modern berpengaruh positif pada kepatuhan wajib pajak, hal ini menunjukkan bahwa semakin baik system administrasi perpajakan yang diterapkan maka kepatuhan wajib pajak akan meningkat. Fahmi (2014) meneliti tentang modernisasi sistem administrasi perpajakan terhadap tingkat kepatuhan pengusaha kena pajak di KPP Pratama Padang. Hasil penelitian menunjukkan bahwa ada pengaruh positif antara modernisasi sistem perpajakan dengan tingkat kepatuhan Wajib Pajak. Hasil tersebut sejalan dengan penelitian yang dilakukan oleh Madewing (2013) yang meneliti tentang Pengaruh Modernisasi Sistem Administrasi Perpajakan terhadap kepatuhan Wajib Pajak pada KPP Pratama Makasar Utara.

Sistem administrasi perpajakan jika dikatitkan dengan Theory of Planned Behavior, yaitu berkaitan dengan normatif beliefs yang merupakan keyakinan tentang harapan normatif orang lain yang menjadi rujukannya dan motivasi untuk memenuhi harapan tersebut. Sistem administrasi perpajakan yang baik serta memadai akan membuat wajib pajak memiliki keyakinan, termotivasi dan memilih perilaku taat pajak. Pelayanan dan pengawasan yang baik, proses administrasi yang efisien dan efektif, keramah-tamahan petugas pajak serta kemudahan dalam membayar pajak diharapkan mampu memotivasi wajib pajak untuk patuh dalam membayar dan memenuhi kewajiban perpajakannya. 
Berdasarkan Tabel 4. diperoleh nilai t untuk variabel kualitas pelayanan sebesar 2,857 dan nilai signifikansi uji t sebesar 0,005 lebih kecil dari $\alpha=0,05$ dan nilai koefisien regresi sebesar 0,225, maka $\mathrm{H}_{2}$ diterima. Hasil pengujian menunjukkan bahwa kualitas pelayanan berpengaruh positif pada kepatuhan wajib pajak, hal ini menunjukkan apabila kualitas pelayanan yang diberikan baik, maka akan meningkatkan kepatuhan wajib pajak. Putri (2017) yang menunjukan bahwa kualitas pelayanan berpengaruh positif dan signifikan pada kepatuhan pelaporan wajib pajak orang pribadi. Kualitas pelayanan yang baik dapat memberikan rasa puas kepada wajib pajak atas pelayanan yang diterima pada saat memenuhi kewajiban perpajakannya. Kepuasan yang dirasakan wajib pajak atas pelayanan yang diterima dapat meningkatkan kesadaran akan tanggungjawabnya sebagai wajib pajak untuk patuh dalam melaksanakan kewajiban perpajakannya yang pada akhirnya akan meningkatkan penerimaan negara khususnya di sektor pajak. Hasil penelitian tersebut sejalan dengan penelitian yang dilakukan oleh Rusmayani dan Supadmi (2017) yang membuktikan bahwa kualitas pelayanan berpengaruh positif dan signifikan terhadap kepatuhan wajib pajak.

Kualitas pelayanan jika dikaitkan dengan Theory of Planned Behavior, yaitu normative belief relevan untuk menjelaskan perilaku wajib pajak dalam memenuhi kewajiban perpajakannya. Normative belief merupakan keyakinan individu tentang harapan normatif orang lain yang menjadi rujukannya dan motivasi untuk memenuhi harapan tersebut. Pelayanan pajak yang berkualitas dari petugas KPP Pratama Denpasar Timur, akan membuat wajib pajak memiliki keyakinan, termotivasi dan memilih perilaku taat pajak. Keramah-tamahan 
petugas pajak serta kemudahaan dalam pembayaran dan sistem informasi perpajakan akan memberikan kesan yang baik bagi setiap wajib pajak dalam membayar pajak, sehingga diharapkan kualitas pelayanan yang baik ini akan meningkatkan kepatuhan masyarakat atau wajib pajak dalam membayar dan memenuhi kewajiban perpajaknnya.

Berdasarkan Tabel 4. diperoleh nilai t untuk variabel kesadaran wajib pajak sebesar 2,809 dan nilai signifikansi uji t sebesar 0,006 lebih kecil dari $\alpha=$ 0,05 dan nilai koefisien regresi sebesar 0,299, maka $\mathrm{H}_{3}$ diterima. Hasil pengujian menunjukkan bahwa kesadaran wajib pajak berpengaruh positif pada kepatuhan wajib pajak, hal ini menunjukkan bahwa semakin tinggi tingkat kesadarn wajib pajak akan kewajiban perpajakannya maka kepatuhan wajib pajak akan meningkat. Penelitian yang dilakukan Megawangi (2016) dan Pratiwi dan Ery (2014) membuktikan bahwa kesadaran Wajib Pajak berpengaruh positif pada kepatuhan Wajib Pajak. Hal tersebut juga didukung oleh penelitian-penelitian yang dilakukan oleh Rohmawati dan Rasmini (2012) serta Dewi dan Lely (2017) yang membuktikan bahwa kesadaran Wajib Pajak, penyuluhan, pelayanan, dan sanksi perpajakan berpengaruh positif pada kepatuhan Wajib Pajak Orang Pribadi.

Teori kepatuhan dapat digolongkan dalam teori konsensus dan teori paksaan. Bagi teori konsensus, dasar ketaatan terletak pada penerimaan masyarakat terhadap sistem hukum. Teori konsensus memiliki kaitan dalam hal kepatuhan perpajakan, dengan tanggung jawab moral dan kesadaran wajib pajak akan pentingnya fungsi maupun manfaat dari pajak, maka akan tercipta suatu penerimaan dari wajib pajak mengenai sistem perpajakan yang sesuai dengan 
ketentuan yang berlaku. Kesadaran wajib pajak dalam teori konsensus juga merupakan salah satu faktor yang dapat mempengaruhi perilaku wajib pajak dalam membayar pajak. Kesadaran wajib pajak merupakan kondisi dimana wajib pajak mengetahui, mematuhi, dan melaksanakan kewajiban perpajakan dengan benar dan sukarela. Apabila pemahaman dan pelaksanaan kewajiban perpajakan semakin baik, maka tingkat kesadaran wajib pajak semakin tinggi diharapkan dapat meningkatkan kepatuhan perpajakannya.

Hasil penelitian ini dapat memberikan tambahan informasi mengenai pengaruh sistem administrasi perpajakan modern, kualitas pelayanan dan kesadaran wajib pajak pada kepatuhan wajib pajak orang pribadi. Terdapat bukti empiris bagi peneliti dalam pengaruh sistem administrasi perpajakan modern, kualitas pelayanan, dan kesadaran wajib pajak pada kepatuhan wajib pajak. Sesuai dengan theory of planned behavior menyatakan bahwa perilaku yang ditimbulkan oleh individu muncul karena adanya niat untuk berperilaku. Theory of Planned Behavior dapat menjelaskan secara relevan perilaku wajib pajak dalam memenuhi kewajiban perpajakannya. Sebelum seseorang melakukan perbuatan, orang tersebut akan memiliki keyakinan akan hasil yang diperoleh dari perbuatannya tersebut. Kemudian orang itu akan memutuskan bahwa akan melakukannya atau tidak melakukannya.

Hasil penelitian ini mampu digunakan sebagai referensi, masukan dan tambahan informasi bagi wajib pajak orang pribadi bahwa kepatuhan wajib pajak dapat membantu penerimaan negara yang nantinya dapat digunakan untuk pembangunan nasional serta meningkatkan kesejahteraan seluruh lapisan 
masyarakat. Penelitian ini juga diharapkan dapat menjadi sumbangan pemikiran dan bahan pertimbangan oleh pihak pembuat kebijakan perpajakan, serta menjadi pedoman bagi penelitian selanjutnya.

\section{SIMPULAN}

Berdasarkan hasil analisis data dan pembahasan pada bab sebelumnya, maka dapat ditarik simpulan bahwa sistem administrasi perpajakan modern berpengaruh positif pada kepatuhan wajib pajak orang pribadi di Kantor Pelayanan Pajak Pratama Denpasar Timur. Hal ini menunjukkan bahwa semakin baik sistem administrasi perpajakan yang diberikan oleh fiskus, maka kepatuhan wajib pajak juga akan meningkat.

Kualitas pelayanan berpengaruh positif pada kepatuhan wajib pajak orang pribadi di Kantor Pelayanan Pajak Pratama Denpasar Timur. Wajib pajak yang mendapatkan kualitas pelayanan yang memadai dan memuaskan membuat kepatuhan wajib pajak meningkat.

Kesadaran wajib pajak berpengaruh positif pada kepatuhan wajib pajak

orang pribadi di KPP Pratama Denpasar Timur. Wajib pajak yang sadar melaksanakan kewajiban perpajakannya akan meningkatkan kepatuhan wajib pajak tersebut.

Berdasarkan hasil penelitian dan simpulan diatas adapun saran yang dapat diberikan adalah bagi Kantor Pelayanan Pajak Pratama Denpasar Timur. Diperlukannya peningkatan fungsi dari Account Representative yang khusus bertugas melayani dan mengawasi pemenuhan kewajiban perpajakan secara langsung. Mengoptimalkan penggunaan sistem administrasi agar mampu 
membangun kenyamanan antar fiskus dan wajib pajak sehingga meningkatkan kepatuhan wajib pajak dalam membayar dan melaporkan kewajiban perpajakannya.

Penelitian selanjutnya lebih memperluas wilayah penelitian serta menambah jumlah responden penelitian untuk lebih memperluas persepsi wajib pajak mengenai pengaruh modernisasi sistem administrasi perpajakan.Diharapkan penelitian selanjutnya lebih meneliti tingkat kepatuhan wajib pajak di Kantor Pelayanan Pajak Pratama Denpasar Timur yang difokuskan pada variabel-variabel yang tidak diteliti sebesar 66,4 persen yang mungkin lebih dominan memengaruhi tingkat kepatuhan wajib pajak seperti sanksi pajak, biaya kepatuhan pajak.Diharapkan penelitian selanjutnya lebih memerhatikan ketepatan responden dalam menjawab pernyatan agar tidak salah sasaran.

\section{REFERENSI}

Chau, Liung. 2009. A Critical Review of Fisher Tax Compliance Model (A Research Syntesis). Journal of Accounting and Taxation, 1 (2), pp: 34-40.

Dewi, Gek Ayu Putu Intan Permata. 2018. Faktor-Faktor Yang Mempengaruhi Tingkat Kepatuhan Wajib Pajak Orang Pribadi di Kantor Pelayanan Pajak Pratama Badung Utara. E-Jurnal Akuntansi Universitas Udayana, 23 (2), hal. 1277-1304.

Dewi, IGA. Cahaya Shinta dan Ni Luh Supadmi. 2014. Pengaruh Pemeriksaan Pajak, Kesadaran, Kualitas Pelayanan pada Tingkat Kepatuhan Wajib Pajak Badan. E-Jurnal Akuntansi Universitas Udayana, 9 (2), hal. 505514.

Dewi, Santi Krisna . 2017. Pengaruh Kesadaran Wajib Pajak, Sanksi Perpajakan, E-Filling, dan Tax Amnesty Terhadap Kepatuhan Pelaporan Wajib Pajak. E-Journal Akuntansi Universitas Udayana, 22 (2), hal.1626-1655.

Dharma, Gede Pani Esa dan Ketut Alit Suardana. 2014. Pengaruh Kesadaran Wajib Pajak, Sosialisasi Perpajakan dan Kualitas Pelayanan Terhadap 
Kepatuhan Wajib Pajak dalam Membayar Pajak Kendaraan Bermotor (PKB) dan Pajak Bea Balik Nama Kendaraan Bermotor (BBNKB) pada Kantor Bersama SAMSAT Denpasar. E-Jurnal Akuntansi Universitas Udayana, 6 (1), hal. 340-353

Dharmayasa, I.G. 2016. Pengaruh Modernisasi Sistem Administrasi Perpajakan pada Kepatuhan Wajib Pajak Orang Pribadi. E-JurnalAkuntansi Universitas Udayana, 6 (1), h: 340-353.

Diatnyani, Ida Ayu. 2010. Pengaruh Kesadaran Wajib Pajak, Kualitas Pelayanan, dan Biaya Kepatuhan Pajak pada Kepatuhan Pelaporan Wajib Pajak Orang Pribadi di Kantor Pelayanan Pajak Pratama Denpasar Barat. Skripsi. Sarjana Jurusan Akuntansi Fakultas Ekonomi Universitas Udayana.

Direktorat Jendral Pajak. 2007. Laporan Tahunan Direktorat Jendral Pajak 2007. Modernisasi Sistem Administrasi Perpajakan. Jakarta.

Doran, Michael. 2009. Tax Penaltie and Tax Comliance. Harvard Journal On Legislation Vol.46, page: 111-116.

Fahmi, L., \& Fauzan Misra. 2014. Pengaruh Modernisasi Sistem Administrasi Perpajakan Terhadap Tingkat Kepatuhan Pengusaha Kena Pajak di KPP Pratama Padang. Jurnal Akuntansi Multiparadigma Vol. 5 No. 1, 1-169.

Ghimire, Banshidhar. 2006. Study for the Measures of Tax Compliance Habit and Leakage Control. Journal of Finance and Management in Public Services, 12 (2), pp: 127-142.

Green, L. 1991. Precede-Proceed Framework. Colombia. My Field Publishing Company.

Irawan, Hasan. 2013. Pengaruh Sistem Administrasi Perpajakan Modern terhadap Kepatuhan Wajib Pajak pada Kantor Pelayanan Pajak Madya Palembang. Jurnal Akuntansi STIE MDP.

James, Simon dan Clinton Alley. 2004. Tax Compliance, Self-Assesment and Tax Adminstration. Journal of Finance and Management in Public Service, 2(2), pp: 27:42.

Kennedy, Kathryn. 2005. Tax Management Compensation Planning. Journals Compensation Management Tax Planning, pp: 291-312.

Lederman, Leandra. 2003. The Interplay Between Norms and Enforcement in Tax Compliance. Ohio State Law Journal, 64 (6), hal. 1453-1514. 
Megawangi, Cokorda Agung Meggy dan Putu Ery Setiawan. 2016. Sosialisasi Perpajakan sebagai Pemoderasi Pengaruh Kesadaran Wajib Pajak dan Kualitas Pelayanan pada Kepatuhan Wajib Pajak Badan Di Kantor Pelayanan Pajak Pratama Gianyar.E-journal Akuntansi Universitas Udayana.

Muliari, Ni Ketut dan Putu Ery Setiawan. 2011. Pengaruh Persepsi Tentang Sanksi Perpajakan Dan Kesadaran Wajib Pajak Pada Kepatuhan Pelaporan Wajib Pajak Orang Pribadi Di Kantor Pelayanan Pajak Pratama Denpasar Timur. Jurnal Akuntansi dan Bisnis.

Munawaroh, Siti., Haris Wibisono dan Intan Immanuela. 2014. Faktor-Faktor yang Mempengaruhi Kemauan untuk Membayar Pajak Wajib Pajak Orang Pribadi yang Melakukan Pekerjaan Bebas (Studi Pada KPP Pratama Kota Madiun). Jurnal Riset Manajemen dan Akuntansi. 2 (1), hal. 35 - 44.

Nalendro, Tantra Ikhlas dan Isgiyarta. 2014. Faktor-faktor yang Mempengaruhi Kepatuhan Membayar Pajak Wajib Pajak Orang Pribadi yang Berwirausaha dengan Lingkungan sebagai Variabel Moderasi (Studi Empiris di KPP Pratama Kudus). Diponegoro Journal of Accounting, 3(3), hal. 1-15.

Niemirowski, Pauline, Steve Baldwin and Alexander J Wearing. 2003. Tax Related Behaviours, Beliefs, Attitudes And Values And Taxpayer Compliance In Australia. Journal Of Australian Taxation, 6 (1), pp: 132165 .

Novitasari, Rosalina. 2015. Pengaruh Kesadaran Wajib Pajak, Sosialisasi Perpajakan dan Kualitas Pelayanan pada Kepatuhan Wajib Pajak di SAMSAT Semarang III. Skripsi. Semarang: Universitas Dian Nuswantoro.

Palupi, E. 2010. Pengaruh Penerapan Sistem Administrasi Perpajakan Modern terhadap Kepatuahn Wajib Pajak dan Penerimaan Pajak Penghasilan Orang Pribadi pada Kantor Pelayanan Pajak Pratama Jakarta Gambir Empat. Tesis. Program Pasca Sarjana Magister Sains Ilmu Administrasi Universitas Indonesia.

Pamuji, Adi Ratno, Mochammad Djudi Mukzam dan Nengah Sudjana. 2014. Faktor-Faktor yang Mempengaruhi Kepatuhan Pemilik Usaha Mikro, Kecil, dan Menengah (UMKM) dalam Memenuhi Kewajiban Perpajakan(Studi pada Wajib Pajak Pemilik UMKM Di KPP Pratama Malang Selatan). Jurnal Mahasiswa Perpajakan, 3 (1), hal. 1-9.

Patmasari, Eken.,Trimurti dan Suhendro. 2016. Pengaruh Pelayanan, Sanksi, Sistem Perpajakan Kesadaran Wajib Pajak, terhadap Kepatuhan Membayar Pajak Bumi dan Bangunan di Desa Tirtosuworo, Giriwoyo, Wonogiri. Seminar Nasional IENACO. 
Parasuraman, A., Valarie A. Zeithaml, \& Leonard L. Berry. 1988. Conceptual Model of Service Quality and Its Implications for Future Research. The Journal of Marketing, 49 (4), hal. 41-50.

Prabawa, Made Adi Mertha dan Naniek Noviari. 2012. Pengaruh Kualitas Pelayanan dan Sikap Terhadap Kepatuhan Pelaporan Wajib Pajak Orang Pribadi di KPP Badung Utara. E-jurnal Akuntansi Universitas Udayana, 1 (2)

Pratiwi, P. 2016. Pengaruh Modernisasi Sistem Administrasi dan Sanksi Perpajakan pada Kepatuhan Wajib Pajak Orang Pribadi di Kantor Pelayanan Pajak Pratama Denpasar Timur. Skripsi. Sarjana Jurusan Akuntansi Fakultas Ekonomi dan Bisnis Universitas Udayana.

Putra, I Gusti Agung Sri Mustika. 2018. Faktor-Faktor Yang Mempengaruhi Kepatuhan Wajib Pajak Kendaraan Bermotor di Kabupaten Gianyar. EJournal Akuntansi Universitas Udayana, 23 (1), hal.461-488.

Putra, I Made Adi Darma dan I Ketut Jati. 2017. Analisis Faktor-Faktor yang Mempengaruhi Kepatuhan Wajib Pajak Kendaraan Bermotor di Kantor Bersama Samsat Tabanan. E-Jurnal Akuntansi Universitas Udayana, 18 (1), hal. 557-587.

Putri, Juniati. 2017. Pengaruh Kesadaran Wajib Pajak, Pengetahuan dan Pemahaman Peraturan Perpajakan, Kualitas Pelayanan dan Sanksi Perpajakan pada Kepatuhan Wajib Pajak Orang Pribadi di KPP Pratama Denpasar Timur. E-Jurnal Akuntansi Universitas Udayana, 18 (2), hal.1112-1140.

Putri, Siswanto, I Ketut Jati. 2014. Faktor-Faktor yang Mempengaruhi Kepatuhan Wajib Pajak dalam Membayar Pajak Kendaraan bermotor di Denpasar. Skripsi. Sarjana Jurusan Akuntansi pada Fakultas Ekonomi dan Bisnis Universitas Udayana.

Redae, Redae Berhe danShailinder Sekhon. 2017. Taxpayers' Moral and Compliance behavior in Ethiopia: A study of Tigray state. International Journal of Research in Finance and Marketing (IJRFM), 7 (4), hal. 109123.

Ritongga, Pandapotan.2011. Analisis Pengaruh Kesadaran dan Kepatuhan Wajib Pajak Terhadap Kinerja Kantor Pelayanan Pajak dengan PelayananWajib Pajak Sebagai Variabel Intervening di Kantor Pelayanan Pajak Medan Timur, Universitas Islam Sumatera Utara, Medan. 
Rukmana, Dian Ayu. 2013. Pengaruh Kualitas Pelayanan Perpajakan, Kinerja Lembaga Terhadap Kepatuhan Wajib Pajak Pada Kantor Pelayanan Pajak (KPP) Pratama Tanjungpinang.Jurnal Elektronik Tugas Akhir Mahasiswa.

Rusmayani, Ni Made Lisa dan Ni Luh Supadmi. 2017. Pengaruh Sosialisasi, Pengetahuan, Sanksi dan Kualitas Pelayanan Pada Kepatuhan Wajib Pajak Kendaraan Bermotor. E-Jurnal Akuntansi Universitas Udayana, 20 (1), hal. 173-201.

Rustiyaningsih, Sri. 2011. Factor-Faktor yang Mempengaruhi Kepatuhan Wajib Pajak. Widya Warta No. 02 Tahun XXXV, hal. 44-45.

Sentanu, I Nyoman Wirya dan Putu Ery Setiawan. 2016. Pengaruh Kualitas Pelayanan, Kewajiban Moral dan Sanksi Perpajakan pada Kepatuhan Wajib Pajak Hotel. E-Jurnal Akuntansi Universitas Udayana, 16 (1), hal. 306-332.

Siat, Christian Cahyaputra dan Agus Arianto Toly. 2013. Faktor-Faktor yang Mempengaruhi Kepatuhan Wajib Pajak dalam Memenuhi Kewajiban Membayar Pajak di Surabaya. Tax \& Accounting Review, 1 (1), hal. 41-48.

Sugiyono. 2017. Metode Penelitian (Kuantitatif, Kualitatif, dan R\&D). Bandung: Alfabeta

Sukarma, Dwi Anggreni dan Dewa Gede Wirama. 2016. Locus Of Control Sebagai Pemoderasi Pengaruh Kualitas Pelayanan dan Sanksi Perpajakan Pada Kepatuhan Wajib Pajak. E-jurnal Akuntansi Universitas Udayana, 5 (7), hal. 2161-2190.

Supadmi, Ni Luh. 2009. Meningkatkan Kepatuhan Wajib Pajak Melalui Kualitas Pelayanan. Audit Jurnal Akuntansi dan Bisnis, 4 (2), h: 214-219.

Supadmi, Ni Luh. 2009. Meningkatkan Kepatuhan Wajib Pajak melalui Kualitas Pelayanan. Journal Akuntansi dan Bisnis, 4(2).

Widiastuti, Riana dan Herry Laksito. 2014. Faktor-Faktor yang Mempengaruhi Kepatuhan Pajak Bumi dan Bangunan P-2 (Studi Kasus Wajib Pajak Orang Pribadi di Kabupaten Klaten). Diponegoro Journal of Accounting, 3 (2), hal. 1-15.

Widyawati dan Nurlis. 2010. Faktor-Faktor Yang Mempengaruhi Kemauan Untuk Membayar Pajak Wajib Pajak Orang Pribadi Yang Melakukan Pekerjaan Bebas (Studi Kasus pada Kantor Pelayanan Pajak Pratama Gambir Tiga). 
Ni Luh Putu Yunika Antari dan Ni Luh Supadmi. Pengaruh...

Jurnal Simposium Nasional Akuntansi (SNA) XIII: Universitas Jendral Soedirman, Purwokerto.

Yasa, I Putu Risky Perdana dan I Ketut Jati. 2017. Kondisi Keuangan Wajib pajak Pemoderasi Pengaruh Sanksi Perpajakan, Kesadaran Wajib Pajak Pada Kepatuhan Wajib Pajak. E-journal Akuntansi Universitas Udayana, 19 (2), hal. 1521-1550. 